BMJ Open

Diabetes

Research

\& Care

\section{Glucose homeostasis is impaired in mice deficient in the neuropeptide 26RFa (QRFP)}

To cite: El-Mehdi M, Takhlidjt S, Khiar F, et al. Glucose homeostasis is impaired in mice deficient in the neuropeptide 26RFa (QRFP). BMJ Open Diab Res Care 2020;8:e000942. doi:10.1136/ bmjdrc-2019-000942

- Additional material is published online only. To view please visit the journal online (http://dx.doi.org/10.1136/ bmjdrc-2019-000942).

Received 9 October 2019 Revised 9 January 2020 Accepted 28 January 2020

\section{Check for updates}

(C) Author(s) (or their employer(s)) 2020. Re-use permitted under CC BY-NC. No commercial re-use. See rights and permissions. Published by BMJ.

${ }^{1}$ U1239, INSERM, Rouen, France

${ }^{2}$ SCAC, Normandy University, Rouen, France ${ }^{3}$ UMR6265, CNRS, Dijon, France

Correspondence to Dr Nicolas Chartrel; nicolas.chartrel@univ-rouen.fr

\section{ABSTRACT}

Introduction 26RFa (pyroglutamyl RFamide peptide (QRFP)) is a biologically active peptide that has been found to control feeding behavior by stimulating food intake, and to regulate glucose homeostasis by acting as an incretin. The aim of the present study was thus to investigate the impact of 26RFa gene knockout on the regulation of energy and glucose metabolism.

Research design and methods 26RFa mutant mice were generated by homologous recombination, in which the entire coding region of prepro26RFa was replaced by the iCre sequence. Energy and glucose metabolism was evaluated through measurement of complementary parameters. Morphological and physiological alterations of the pancreatic islets were also investigated.

Results Our data do not reveal significant alteration of energy metabolism in the 26RFa-deficient mice except the occurrence of an increased basal metabolic rate. By contrast, 26RFa mutant mice exhibited an altered glycemic phenotype with an increased hyperglycemia after a glucose challenge associated with an impaired insulin production, and an elevated hepatic glucose production. Two-dimensional and three-dimensional immunohistochemical experiments indicate that the insulin content of pancreatic $\beta$ cells is much lower in the $26 \mathrm{RFa}^{-1-}$ mice as compared with the wild-type littermates.

Conclusion Disruption of the 26RFa gene induces substantial alteration in the regulation of glucose homeostasis, with in particular a deficit in insulin production by the pancreatic islets. These findings further support the notion that 26RFa is an important regulator of glucose homeostasis.

\section{INTRODUCTION}

Obesity and diabetes are considered worldwide epidemic issues. Indeed, in 2016, 650 million adults were classified as clinically obese, ${ }^{1}$ and 300 million people are affected by type 2 diabetes (T2DM) worldwide (http:// www.idf.org/). Obesity and T2DM are two strongly associated diseases, as $80 \%$ of people developing T2DM are obese, with insulin resistance a common feature of both obesity and diabetes, raising therefore the hypothesis

\section{Significance of this study}

What is already known about this subject?

- 26RFa is a biologically active peptide produced in abundance in the gut and the pancreas.

- 26RFa has been found to regulate glucose homeostasis by acting as an incretin and by increasing insulin sensitivity.

What are the new findings?

- Disruption of the 26RFa gene induces substantial alteration in the regulation of glucose homeostasis, with in particular a deficit in insulin production by the pancreatic islets, assessing therefore the notion that 26RFa is an important regulator of glucose homeostasis.

How might these results change the focus of research or clinical practice?

- Identification of a novel actor in the regulation of glucose homeostasis is crucial to better understand the general control of glucose metabolism in physiological and pathophysiological conditions, and opens new fields of investigation to develop innovative drugs to treat diabetes mellitus.

that obesity and diabetes may arise from a common functional defect.

Interestingly, accumulating data obtained during the last decade revealed that a number of neuropeptides well known to control feeding behavior, such as neuropeptide Y (NPY), orexins, ghrelin, corticotropinreleasing factor (CRF) or apelin, may also regulate glucose homeostasis. ${ }^{2-6}$ It was also found that the neuropeptidergic systems controlling feeding behavior and glucose homeostasis in the hypothalamus partially overlap. ${ }^{78}$ From these observations suggesting that neuropeptides may link energy and glucose homeostasis emerged a new concept proposing that the pathogenesis of obesity and diabetes may originate from defects of 
the neuropeptidergic systems controlling both energy and glucose homeostasis. ${ }^{9}$

In this context, the neuropeptidergic system, the $26 \mathrm{RFa} / \mathrm{GPR} 103$ system, is of particular interest. 26RFa (also referred to as pyroglutamyl RFamide peptide $(\mathrm{QRFP}))$ is a hypothalamic neuropeptide discovered concurrently by us and others. ${ }^{10-12} 26 \mathrm{RFa}$ has been characterized in all vertebrate phyla including human, ${ }^{1314}$ and identified as the cognate ligand of the human orphan G protein-coupled receptor, GPR103. ${ }^{11-13} 1516$ Neuroanatomical observations revealed that 26RFa-expressing and GPR103-expressing neurons are primarily localized in hypothalamic nuclei involved in the control of feeding behavior. ${ }^{1011} 151718$ Indeed, intracerebroventricular administration of 26RFa stimulates food intake, ${ }^{1015} 1920$ and the neuropeptide exerts its orexigenic activity by modulating the NPY/proopiomelanocortin (POMC) system in the arcuate nucleus. ${ }^{20} 26 \mathrm{RFa}$ also stimulates food intake in birds $^{21}$ and fish, ${ }^{22}$ indicating that $26 \mathrm{RFa}$ plays a crucial role in the central regulation of body weight and energy homeostasis in all vertebrates. Interestingly, a more sustained orexigenic activity of 26RFa was reported in obese rodents. ${ }^{1923}$ In addition, expression of prepro26RFa mRNA is upregulated in the hypothalamus of genetically obese $o b / o b$ and $d b / d b$ mice, ${ }^{15}$ and in rodents submitted to a high-fat diet, ${ }^{19}{ }^{23}$ and the plasma levels of the neuropeptide are increased in obese patients. ${ }^{24} 25$ Finally, 26RFa was found to trigger lipid uptake and to inhibit lipolysis in obese individuals. ${ }^{26}$ Altogether, these findings support the notion that $26 \mathrm{RF}$ a could play a role in the development and maintenance of the obese status. ${ }^{14}$

More recently, the implication of the 26RFa/GPR103 neuropeptidergic system in the control of glucose homeostasis was reported. We and others found that 26RFa and GPR103 are strongly expressed by $\beta$ cells of the pancreatic islets, ${ }^{242527}$ and that the neuropeptide prevents cell death and apoptosis of $\beta$ cells. ${ }^{27}$ We also showed that $26 \mathrm{RFa}$ is abundantly expressed all along the gut and that intraperitoneal administration of the neuropeptide attenuates glucose-induced hyperglycemia by increasing plasma insulin via a direct insulinotropic effect on the pancreatic $\beta$ cells, and by increasing insulin sensitivity. ${ }^{24}{ }^{25}$ Finally, we reported that an oral glucose challenge induces a massive secretion of $26 \mathrm{RFa}$ by the gut into the blood, strongly suggesting that this neuropeptide regulates glycemia by acting as an incretin. ${ }^{24}$ This incretin effect of $26 \mathrm{RFa}$ has been very recently confirmed by the observation that administration of a GPR103 antagonist reduces the global glucose-induced incretin effect, and also decreases insulin sensitivity. ${ }^{28}$

Together, these findings support the idea that the 26RFa/GPR103 peptidergic system plays an important role in the regulation of energy and glucose homeostasis. Consequently, the objective of the present study was to investigate the impact of altered endogenous 26RFa production on the regulation of energy and glucose metabolism using a model of mice deficient in the $26 \mathrm{RFa}$ gene.

\section{RESEARCH DESIGN AND METHODS}

\section{Animals}

$26 \mathrm{RFa}^{-/-}, 26 \mathrm{RFa}^{+/-}$and $26 \mathrm{RFa}^{+/+}$male $\mathrm{C} 57 \mathrm{Bl} / 6$ mice (2-4 months old), weighing $22-25 \mathrm{~g}$, were housed with free access to standard diet (UAR, Villemoisson-sur-Orge, France) and tap water. They were kept in a ventilated room at a temperature of $22^{\circ} \mathrm{C} \pm 1^{\circ} \mathrm{C}$ under a 12-hour light/12-hour dark cycle (light on between 7:00 and 19:00). All experiments were carried out between 09:00 and 18:00 in the testing rooms adjacent to the animal rooms. Mice were housed at three to five per cage. Unless otherwise stated, all tests were conducted with naïve cohorts of mice that were habituated to physiological and behavior protocols before the beginning of experiments.

\section{Strategy and characterization of mouse 26RFa gene disruption}

26 $\mathrm{RFa}^{-/-}$(iCre knock-in) mice were obtained from Professor T Sakurai (International Institute for Integrative Sleep Medicine, Tsukuba, Ibaraki, Japan). The mutant mice were generated by homologous recombination in embryonic stem cells of 129SvJ strain and implanted in C57 blastocysts using standard procedures. The targeting vector was constructed by replacing the entire coding region of prepro26RFa sequence in exon 2 of the 26RFa gene with iCre sequence and pgk-Neo cassette (online supplementary data 1A).

Genotypes were determined by PCR of DNA mouse tail biopsy. PCR primers used were 5'-CAGTCAGCAGCTATCCCTCC-3' (from 115 to 96 base of the 26RFa gene from the transcription initiation site) and 5'-ACCGTCTT GCCTCCCTAGACG-3' (from 225 to 246 base), and 5'-GAGGGACTACCTCCTGTACC-3' and 5'-TGCCCAGAGTCATCGTTGGC-3' (corresponding to the iCre sequence). We detected a $361 \mathrm{pb}$ product from wild-type allele corresponding to the 26RFa coding sequence, and a $650 \mathrm{pb}$ product from the targeted allele corresponding to the inserted iCre sequence (online supplementary data 1B). Chimeric mice were crossed with $\mathrm{C} 57 \mathrm{Bl} / 6 \mathrm{~J}$ males (Janvier Laboratory, Le Genest-Saint-Isle, France). Initially, F1 hybrids from heterozygous $\times$ heterozygous mating were generated. $26 \mathrm{RFa}^{-/-}$mice and wild-type mice littermates were basically obtained by heterozygous $x$ heterozygous mating.

Immunohistochemical experiments performed on the pancreas and duodenal sections revealed the presence of an intense $26 \mathrm{RFa}$ immunolabeling in the pancreatic islets and the duodenal enterocytes of the wild-type mice, whereas similar sections from 26RFa-deficient mice were totally devoid of staining (figure 1A).

\section{Metabolic phenotype analysis \\ Combined indirect calorimetry}

A 16-cage combined indirect calorimetry system (PhenoMaster, TSE Systems, Bad Homburg, Germany) was used to assess continuous monitoring of energy expenditure, locomotor activity, respiratory quotient (RQ), as well as food and water intake. Mice were individually housed 
A

Pancreas
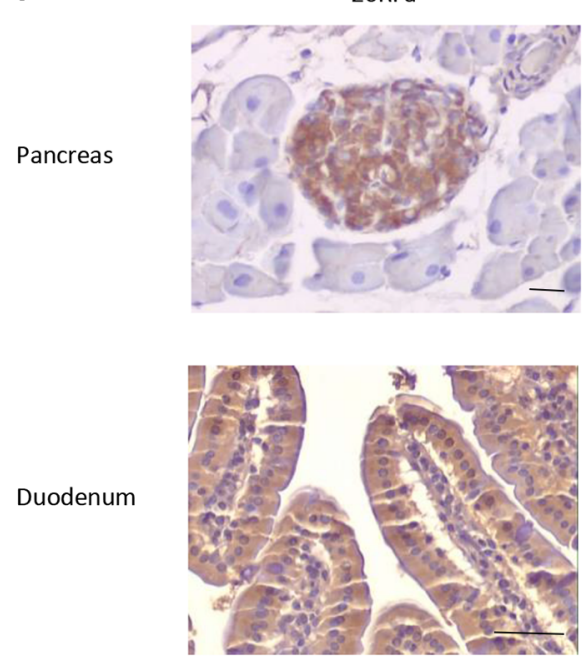
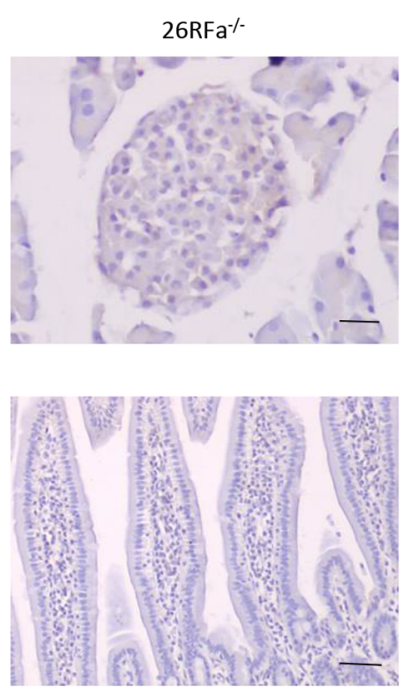

$-26 \mathrm{RFa}^{-/}$

Glycemia evolution
B

Body weight evolution

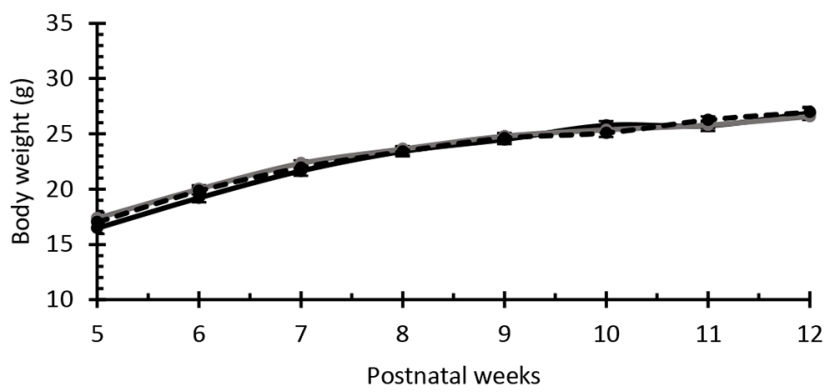

D

Insulinemia evolution

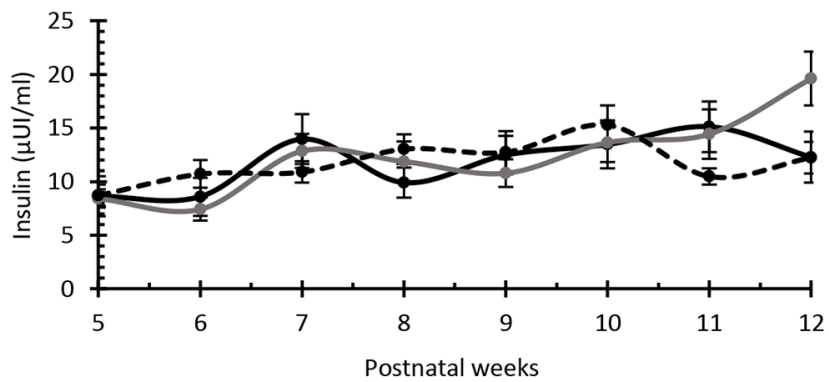

C

\section{$26 \mathrm{RFa}^{+/-}$}

C
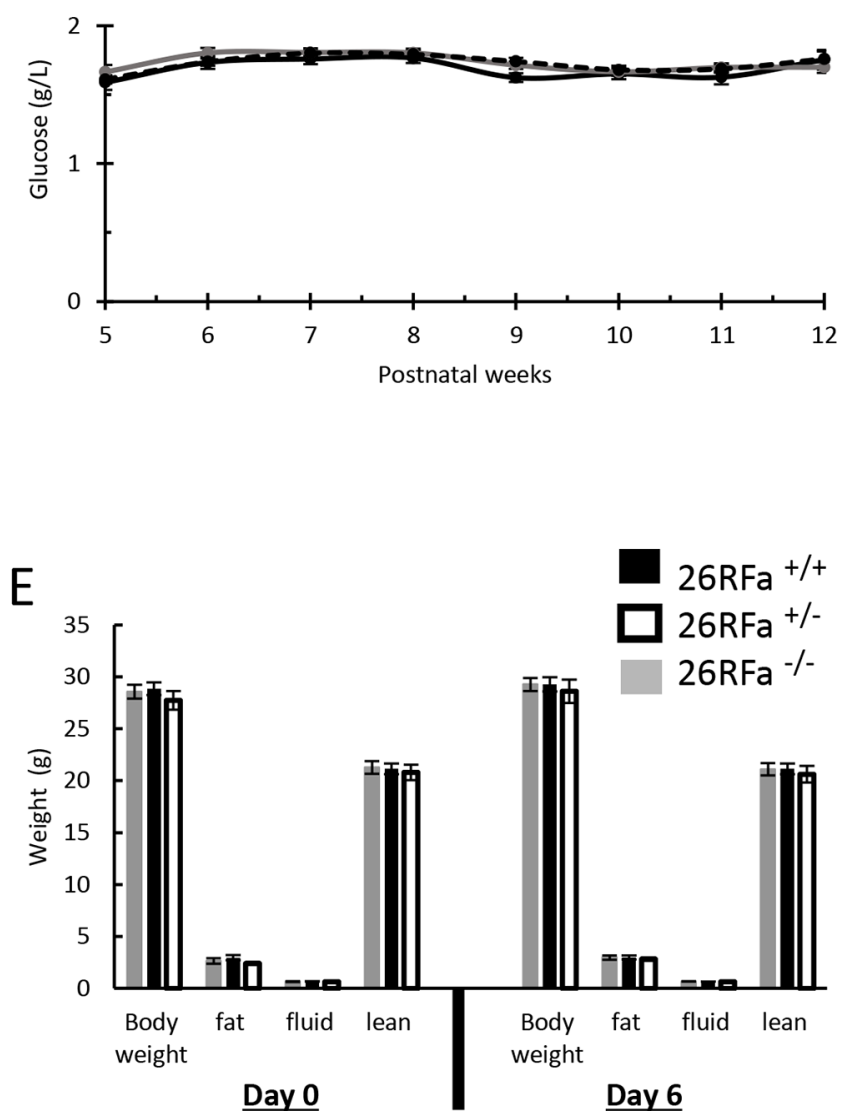

Figure 1 Characterization and body composition of 26RFa-deficient mice. (A) Immunohistochemical photomicrographs of the pancreas and duodenal sections showing complete depletion of the $26 \mathrm{RFa}$ immunostaining in the tissues of the $26 \mathrm{RFa}{ }^{-/-}$mice. Scale bar: $50 \mu \mathrm{m}$. (B-D) Evolution of body weight, glycemia and insulinemia from the 5 th to the 12 th postnatal week $(\mathrm{n}=20-58)$. (E) Evaluation of body mass composition in $26 \mathrm{RFa}^{-/-}, 26 \mathrm{RFa}^{+/-}$and $26 \mathrm{RFa}^{+/+}$mice during a 6-day experimental protocol in which animals were fed ad libitum for 3 days, then were food-restricted for 1 day and refed for 2 days $(n=11$ per group). Data presented as mean \pm SEM. 
and acclimated to the airtight cages for 5 days before the experimental measurements. Subsequently, volumes of oxygen consumption and volumes of $\mathrm{CO}_{2}$ production were measured every minute for a total of six light and six dark phases (144hours) to determine the respiratory quotient $\left(\mathrm{RQ}=\mathrm{VCO}_{2} / \mathrm{VO}_{2}\right)$ and energy expenditure $\left(\mathrm{EE}=\mathrm{VO}_{2} \times\left(3.815+\left(1.232 \times\left(\mathrm{VCO}_{2} / \mathrm{VO}_{2}\right)\right)\right) \times 4.1868\right)$.

The 16-home cage locomotor activity (horizontal and vertical) was determined by a multidimensional infrared light beam system. Stationary locomotor activity was defined as consecutive infrared light beam breaks of one single light beam and ambulatory movement as consecutive breaks of two different light beams.

Scales integrated into the sealed cage environment continuously measured cumulative food intake and water intake. The mice were kept at a constant temperature of $23^{\circ} \mathrm{C}$ for 6 days.

\section{Body composition}

Whole body composition was assessed on vigil animals, before and after metabolic parameter measurements, using MiniSpec LF110 (Bruker, Wissembourg, France), a fast nuclear magnetic resonance method.

\section{Blood glucose and insulin measurements in mice}

For the glycemia and insulinemia profiles of mice between 5 and 12 weeks, the animals were not fasted and measurements were performed between 15:00 and 16:00. For measurements of basal glycemia and insulinemia, mice were fasted 6 hours before the test. For oral or intraperitoneal glucose tolerance test, mice were fasted for 16 hours and then treated intraperitoneally or by gavage with glucose $(2 \mathrm{~g} / \mathrm{kg})$ and $26 \mathrm{RFa}(500 \mu \mathrm{g} / \mathrm{kg})$ for reversion experiments. For insulin tolerance test, mice were fasted for 6 hours before the test with free access to water, and then injected intraperitoneally with 0.75 units $/ \mathrm{kg}$ body weight of human insulin (Eli Lilly, Neuilly-sur-Seine, France). For pyruvate tolerance test, mice were fasted for 16 hours before the test and then injected intraperitoneally with sodium pyruvate $(2 \mathrm{~g} / \mathrm{kg}$; Sigma Aldrich) and $26 \mathrm{RFa}(500 \mu \mathrm{g} / \mathrm{kg})$ for reversion experiments. Plasma glucose concentrations were measured from tail vein samplings at various times using an Accu-Chek Performa glucometer (Roche Diagnostics, Saint-Egreve, France). Plasma insulin concentrations were determined using an ultrasensitive mouse insulin AlphaLisa Detection Kit (cat number AL204C) from Perkin Elmer.

\section{Quantitative PCR}

Total RNA from livers of mice was isolated as previously described ${ }^{28}$ Relative expression of glucose 6 phosphatase (G6PC), glucokinase (GCK) and phosphoenolpyruvate carboxykinase 1 (PCK1) genes was quantified by real-time PCR with appropriate primers (table 1 ). $\beta$-actin was used as internal control for normalization. PCR was carried out using Gene Expression Master Mix 2X assay (Applied Biosystems, Courtaboeuf, France) in an ABI Prism 7900HT Fast Real-Time PCR System (Applied Biosystems). The purity of the PCR products was assessed by dissociation curves. The amount of target cDNA was calculated by the comparative threshold (Ct) method and expressed by means of the 2- $\Delta \Delta \mathrm{Ct}$ method.

\section{Morphological analysis of the pancreas}

Deparaffinized sections (15 $\mu \mathrm{m}$ thick) of $26 \mathrm{RFa}^{-/-}$, $26 \mathrm{RFa}^{+/-}$and $26 \mathrm{RFa}^{+/+}$mice pancreas and duodenum were used for immunohistochemistry. To observe $26 \mathrm{RFa}$ immunolabeling, tissue sections were incubated for 1 hour at room temperature with rabbit polyclonal antibodies against $26 \mathrm{RFa}^{25}$ diluted 1:400. The sections were incubated with a streptavidin-biotin-peroxydase complex (Dako Corporation, Carpinteria, California), and the enzymatic activity was revealed with diaminobenzidine. Some slices were then counterstained with hematoxylin. Observations were made under a Nikon E600 light microscope. To study the morphological architecture, pancreas slices were stained with H\&E and examined under a Leica Z6 APO macroscope and a Nikon E600 light microscope.

For the double labeling experiments, the following primary antibodies were used: guinea pig polyclonal antiinsulin (1:50, GeneTex, Irvine, California) and mouse monoclonal antiglucagon (1:1000, Sigma Aldrich). Alexa-conjugated antibodies (Invitrogen Life Technologies) including goat anti-guinea pig-488 (1:300) and donkey anti-mouse-594 (1:300) were used as secondary antibodies. Sections were counterstained with $1 \mu \mathrm{g} / \mathrm{mL}$ 4',6-diamino-2-phenylindole (Sigma Aldrich) in PBS for 90 s. Tissue sections were examined with a Nikon Eclipse E600. Quantitative, qualitative and morphological analyses of the pancreas sections were performed using the ImageJ software (National Institutes of Health, Washington, DC).

Table 1 Sequence of the primers used for the quantitative PCR experiments

\begin{tabular}{lll}
\hline & Forward primer & Reverse primer \\
\hline Mouse $\beta$-actin & AGGTCATCACTATTGGCA & CACAGGATTCCATACCCAAGAAG \\
Mouse G6PC & TCTGTCCCGGATCTACCTTG & GTAGAATCCAAGCGCGAAAC \\
Mouse GCK & GAGATGGATGTGGTGGCAAT & ACCAGCTCCACATTCTGCAT \\
Mouse PCK & GTGAGGAAGTTCGTGGAAGG & TCTGCTCTTGGGTGATGATG \\
\hline
\end{tabular}

GCK, glucokinase; G6PC, glucose 6 phosphatase; PCK, phosphoenolpyruvate carboxykinase. 


\section{D pancreas analysis}

Treatment of the whole pancreas of the $26 \mathrm{RFa}^{-/-}$and $26 \mathrm{RFa}^{+/+}$mice for immunohistochemistry in toto was performed according to a protocol previously published. ${ }^{29}$ Briefly, the pancreas were fixed by perfusion of paraformaldehyde (PFA) 4\%. After dehydration in successive baths of methanol solution $(20 \%, 40 \%, 60 \%$, $80 \%$ in phosphate buffer saline (PBS) $1 \mathrm{X}$ and $2 \times 100 \%$, 1 hour each), bleaching in $\mathrm{H}_{2} \mathrm{O}_{2}$ and rehydration with successively methanol solution $(100 \%, 80 \%, 60 \%, 40 \%$, $20 \%$ and PBS 1X, 1 hour each), permeabilization was performed by incubating the tissues in a permeabilization solution containing $0.2 \%$ Triton X-100, glycine $0.3 \mathrm{M}$, and $20 \%$ dimethyl sulfoxide (DMSO) for 4 days with rotation at room temperature. Then, antigen blocking was performed by incubating the tissues in PBS containing $0.2 \%$ Triton X-100, $10 \%$ DMSO and 6\% donkey serum for 2 days at $37^{\circ} \mathrm{C}$. The pancreas were incubated in a PBS solution with $0.2 \%$ Tween $20,0.1 \%$ heparin $(10 \mathrm{mg} / \mathrm{mL})$, $5 \%$ DMSO, and 3\% donkey serum with mouse monoclonal insulin antibodies (Sigma Aldrich) at a dilution of 1:200 for 11 days, and then for 6 days with a donkey antimouse IgG (FP-SC4110-E, Interchim) diluted 1:300, used as secondary antibody. The pancreas were cleared during the final steps of iDISCO + protocoland were processed for imaging. For this, the immunolabeled pancreas were visualized in three dimensions using an UltraMicroscope II (Light Sheet Microscope; LaVision BioTec, Bielefeld, Germany) equipped with a Neo sCMOS camera (Andor Technology, Belfast, UK). 3D reconstructions were made using Imaris Software V.8.4 (Bitplane, Zurich, Switzerland).

\section{Statistical analysis}

Statistical analysis was performed with GraphPad Prism (V.6). A Student's t-test or a one-way analysis of variance (ANOVA) was used for comparison between the groups. A two-way ANOVA was used for repeated measures for comparisons between the groups. A post-hoc comparison using Tukey HSD was applied according to the two-way ANOVA results. Statistical significance was set at $\mathrm{p}<0.05$.

\section{RESULTS}

\section{Energy metabolism phenotype of 26RFa-deficient mice}

Measurement of body weight, plasma glucose and insulin levels from postnatal week 5 to week 12 revealed no significant difference between the wild-type, heterozygous and 26RFa-knockout (KO) mice (figure 1B-D). Two-month-old mice of the three groups also followed a 6-day protocol in which the animals were fed ad libitum for 3 days, then were food-restricted for 1 day and refed for 2 days. The body composition analysis showed that $26 \mathrm{RFa}^{-/-}, 26 \mathrm{RFa}^{+/-}$and $26 \mathrm{RFa}^{+/+}$mice had similar body weight, fat mass, lean mass and fluid mass, either at the beginning of the session or at the end of the protocol (figure 1E).
Measurement of food intake throughout the protocol did not reveal any significant difference in the feeding behavior of the three groups of mice, although the 26RFa-KO and the heterozygous mice ate a little bit more than the wild-type controls (figure 2A). Evaluation of water intake indicated the $26 \mathrm{RFa}^{-/-}$mice drank significantly $(\mathrm{p}<0.05)$ more than the wild-type and the heterozygous mice during the test (figure 2B). Measurement of energy expenditure did not reveal any significant variation between the three groups of mice, although the 26RFa-deficient mice exhibited a tendency to increase energy expenditure as compared with the wild-type and heterozygous mice (figure 2C). Metabolic rate measured as $\mathrm{O}_{2}, \mathrm{CO}_{2}$ and $\mathrm{RQ}$ was significantly higher $(\mathrm{p}<0.001)$ in 26RFa-deficient mice as compared with wild-type and heterozygous mice (figure 2D-F). The locomotor activity (horizontal and vertical) was also measured but did not reveal any significant difference between the $26 \mathrm{RFa}^{-/}$, $26 \mathrm{RFa}^{+/-}$and $26 \mathrm{RFa}^{+/+}$mice (figure $2 \mathrm{G}, \mathrm{H}$ ).

\section{Glycemic phenotype of 26RFa-deficient mice}

The 'glycemic' phenotypes of the 26RFa-deficient and the heterozygous mice were investigated using complementary in vivo tests. Basal plasma glucose levels after a 6-hour fasting were comparable in the $26 \mathrm{RFa}^{-/-}, 26 \mathrm{RFa}^{+/-}$ and $26 \mathrm{RFa}^{+/+}$mice (figure $3 \mathrm{~A}$ ). By contrast, basal plasma insulin levels were significantly lower $(p<0.05)$ in the 26RFa-deficient mice as compared with the wild-type and the heterozygous mice (figure 3B). An oral glucose tolerance test indicated that the hyperglycemic and hyperinsulinemic peaks induced by the glucose load were not affected by the lack of 26RFa (figure 3C,D). Conversely, the intraperitoneal glucose tolerance test (IPGTT) revealed a more sustained hyperglycemic peak in the $26 \mathrm{RFa}^{-/-}$mice $(\mathrm{p}<0.05)$, which was associated with a lower rise of plasma insulin levels $(\mathrm{p}<0.05)$ (figure $3 \mathrm{E}, \mathrm{F})$. The heterozygous mice exhibited a glycemic and insulinemic profile during the IPGTT between those of the wild-type and $\mathrm{KO}$ animals (figure $3 \mathrm{E}, \mathrm{F}$ ). Intraperitoneal administration of 26RFa totally reversed the alterations in plasma glucose and insulin observed during the IPGTT in the 26RFa-deficient mice (figure 3G,H) .

The impact of the 26RFa gene disruption on insulin sensitivity and hepatic glucose production was also examined. An insulin tolerance test revealed that insulin sensitivity was not altered in the $26 \mathrm{RFa}^{-/-}$mice and the $26 \mathrm{RFa}^{+/-}$mice as compared with the wild-type animals (figure 4A). By contrast, a pyruvate tolerance test showed that hepatic glucose production was significantly increased in the 26RFa-KO mice in comparison with the wild-type animals $(p<0.05$ and $p<0.01)$ (figure 4B). Intraperitoneal administration of $26 \mathrm{RFa}$ in the $26 \mathrm{RFa}^{-/-}$mice reversed the hyperglycemia observed during the pyruvate tolerance test (figure 4C). In addition, expression of liver enzymes playing a key role in gluconeogenesis and glucogenolysis was determined after a 16-hour fasting, which promotes glucose hepatic production, and was compared with fed condition. As expected, in fasting 

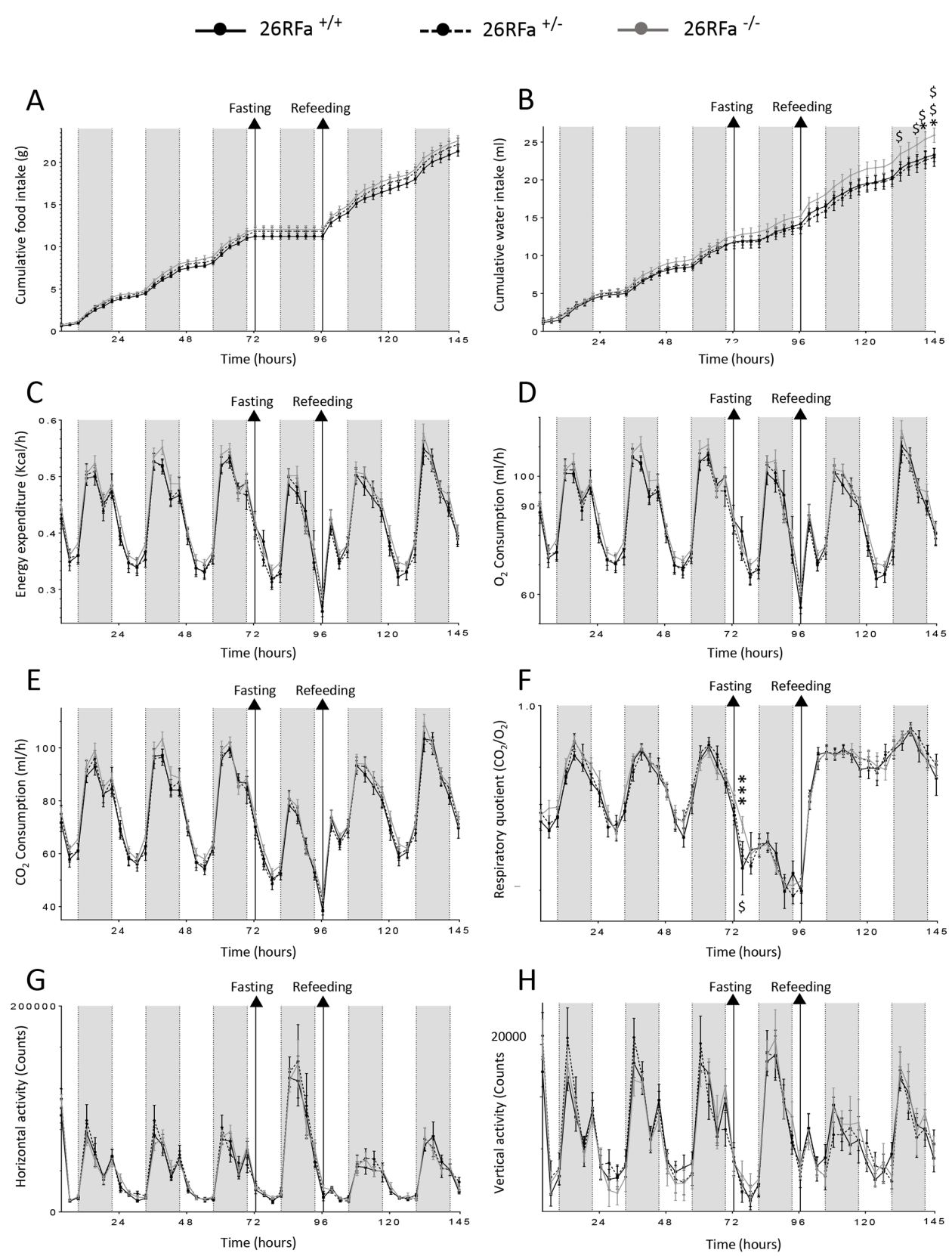

Figure 2 Energy metabolism phenotype of 26RFa-deficient mice. (A-F) Evaluation of various metabolic parameters including feeding (A) and drinking (B) consumption, energy expenditure (C), $\mathrm{O}_{2}$ consumption (D), $\mathrm{CO}_{2}$ consumption $(\mathrm{E})$ and respiratory quotient $(\mathrm{F})$ in $26 \mathrm{RFa}^{-/}, 26 \mathrm{RFa}^{+/-}$and $26 \mathrm{RFa}^{++}$mice during a 6 -day experimental protocol in which animals were fed ad libitum for 3 days, then were food-restricted for 1 day and refed for 2 days ( $n=11$ per group). (G, H) Evaluation of locomotor activity in $26 \mathrm{RFa}^{-/-}, 26 \mathrm{RFa}^{+/-}$and $26 \mathrm{RFa}^{+/+}$mice during the same experimental protocol as in (A-F) ( $\mathrm{n}=11$ per group). Data presented as mean \pm SEM; ${ }^{*} p<0.05,{ }^{* \star *} p<0.00126 \mathrm{RFa}^{-/-}$versus $26 \mathrm{RFa}^{++}{ }^{+/}$mice; ${ }^{\$} \mathrm{p}<0.05,{ }^{\$ \$} \mathrm{p}<0.0126 \mathrm{RFa}^{-/-}$versus $26 \mathrm{RFa}^{+/-}$mice.

condition, wild-type animals showed a drastic decrease in GCK $(\mathrm{p}<0.001)$, which promotes glycogen storage and upregulation of G6PC and PCK1 $(\mathrm{p}<0.05)$, which trigger gluconeogenesis (figure $4 \mathrm{D}$ ). The 26RFa-deficient mice exhibited a different expression profile in fasting condition with a slight decreased expression of GCK associated with a robust increased expression of G6PC and PCK1 $(\mathrm{p}<0.01$ and $\mathrm{p}<0.001)$ (figure $4 \mathrm{E})$.

\section{Pancreatic phenotype of 26RFa-deficient mice}

Comparison of freshly dissected pancreas indicated that the tissues of the 26RFa-KO mice were bigger with more adipose tissues than the wild-type and heterozygous mice, although the weights were similar in the three groups (figure 5A,B). We also observed that the number of pancreatic islets per pancreas tended to be higher in the $26 \mathrm{RFa}^{+/-}$and $26 \mathrm{RFa}^{-/-}$mice, although statistically not significant (figure 5C). In addition, the areas of the pancreatic islets were significantly higher in the 26RFadeficient mice $(p<0.01)$ as compared with the wild-type mice (figure 5D), as illustrated by the photomicrographs in figure $5 \mathrm{E}$. The quantitative analysis also revealed that the total number of $\beta$ cells per pancreas was significantly 
$\longrightarrow 26 \mathrm{RFa}^{+/+}$

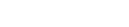

A

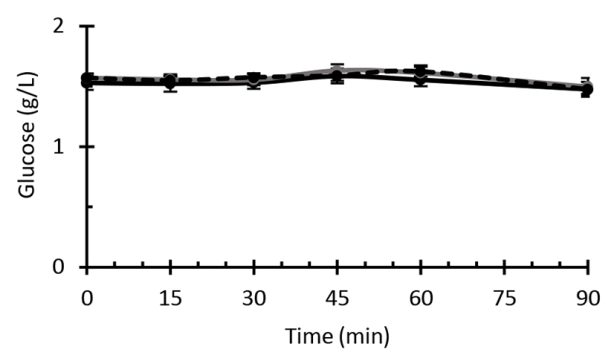

$26 \mathrm{RFa}^{+/-}$

$\longrightarrow 26 \mathrm{RFa}^{-}$

Glucose basal levels

B

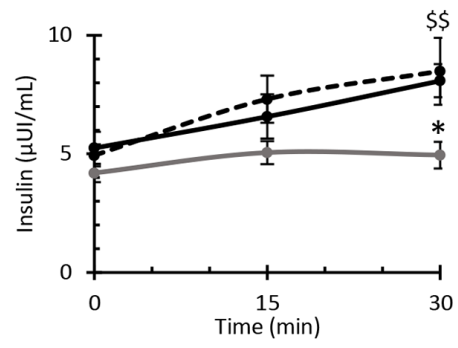

Oral Glucose Tolerance Test

C

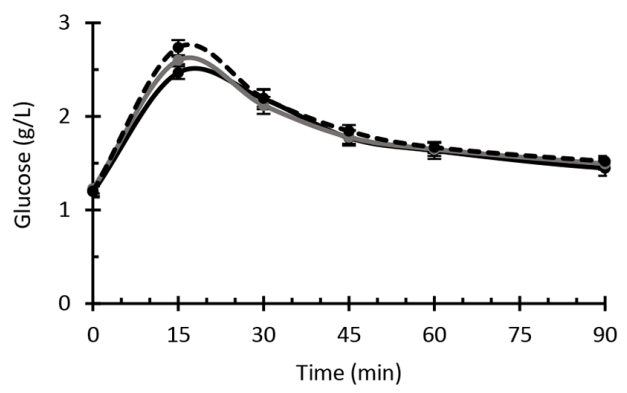

D

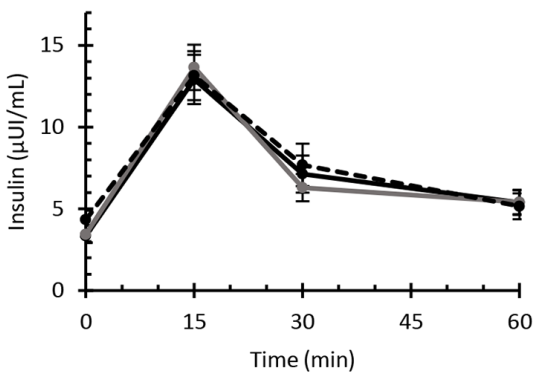

Intraperitoneal Glucose Tolerance Test

E

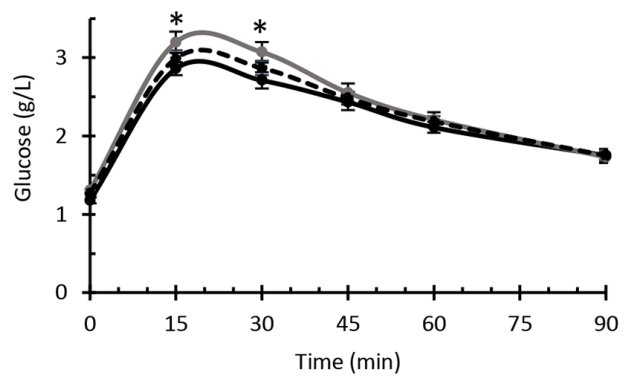

$\mathrm{F}$

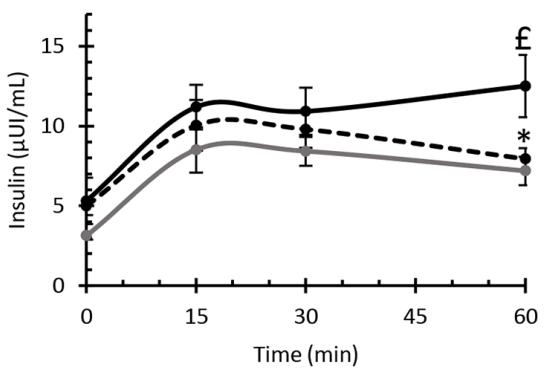

$26 \mathrm{RFa}^{+/+}+$PBS

Intraperitoneal Glucose Tolerance Test reversion

G

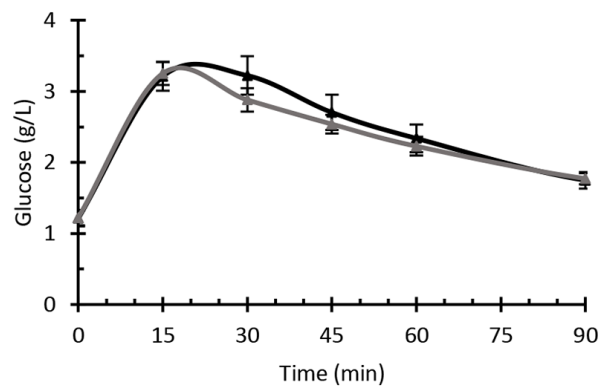

$\mathrm{H}$

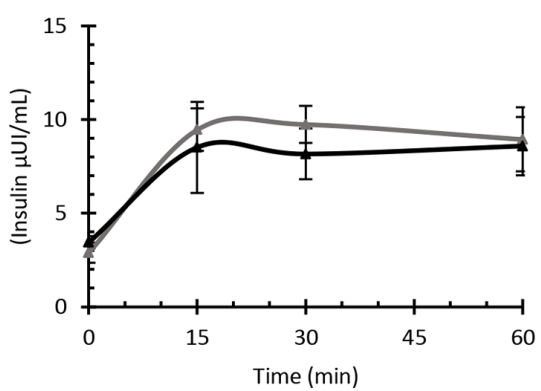

Figure 3 Glycemic phenotype of 26RFa-deficient mice 1. (A, B) Evaluation of plasma glucose and insulin levels in 26RFa ${ }^{-/}$, $26 \mathrm{RFa}^{+/-}$and $26 \mathrm{RFa}^{+/+}$mice in basal condition ( $n=10-18$ per group). (C, D) Evaluation of plasma glucose and insulin levels in $26 \mathrm{RFa}^{-/-}, 26 \mathrm{RFa}^{+/-}$and $26 \mathrm{RFa}^{+/+}$mice during an oral glucose tolerance test ( $n=12-17$ per group). (E, F) Evaluation of plasma glucose and insulin levels in $26 \mathrm{RFa}^{-/-}, 26 \mathrm{RFa}^{+/-}$and $26 \mathrm{RFa}^{+/+}$mice during an intraperitoneal glucose tolerance test $(\mathrm{n}=12-17$ per group). (G, H) Evaluation of plasma glucose and insulin levels in $26 \mathrm{RFa}^{-/-}$mice that received an intraperitoneal dose of $26 \mathrm{RFa}(500 \mu \mathrm{g} / \mathrm{kg})$ during an intraperitoneal glucose tolerance test $(\mathrm{n}=8$ per group). Data presented as mean $\pm \mathrm{SEM}$ of 4 independent experiments; ${ }^{*} \mathrm{p}<0.0526 \mathrm{RFa}^{-/-}$versus $26 \mathrm{RFa}^{+/+}$mice; ${ }^{\$ \$} \mathrm{p}<0.0126 \mathrm{RFa}^{-/-}$versus $26 \mathrm{RFa}^{+/-}$mice; ${ }^{\varepsilon} \mathrm{p}<0.0526 \mathrm{RFa}^{+/-}$ vs $26 \mathrm{RFa}^{+/+}$mice . PBS, phosphate buffer saline. 


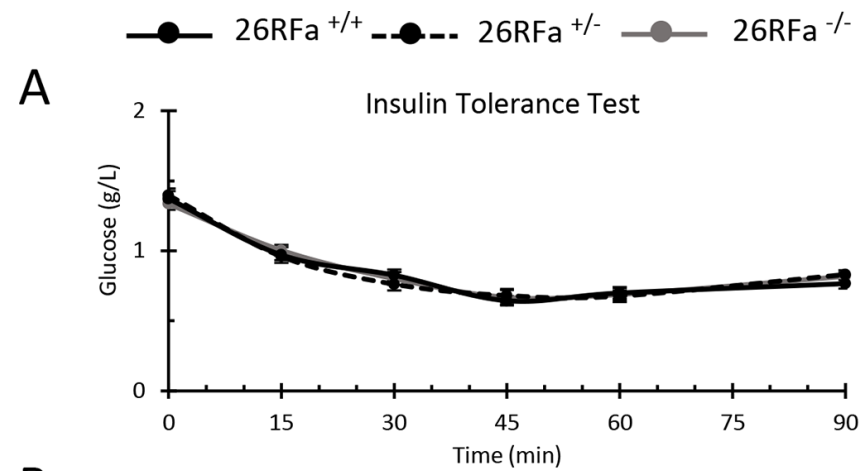

B

Pyruvate Tolerance Test

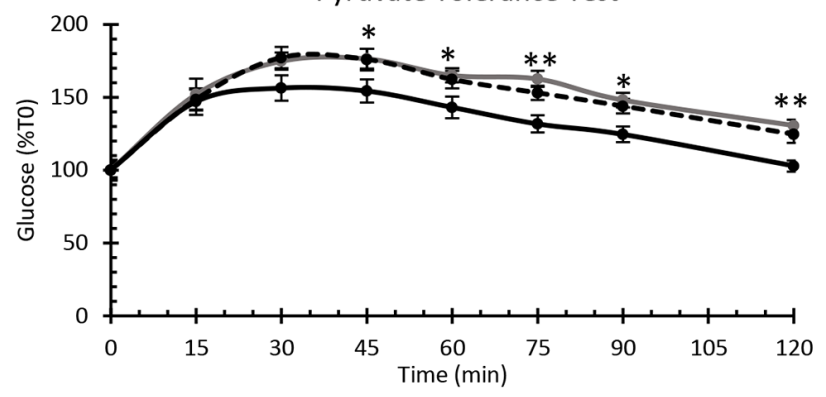

C

Pyruvate Tolerance Test reversion
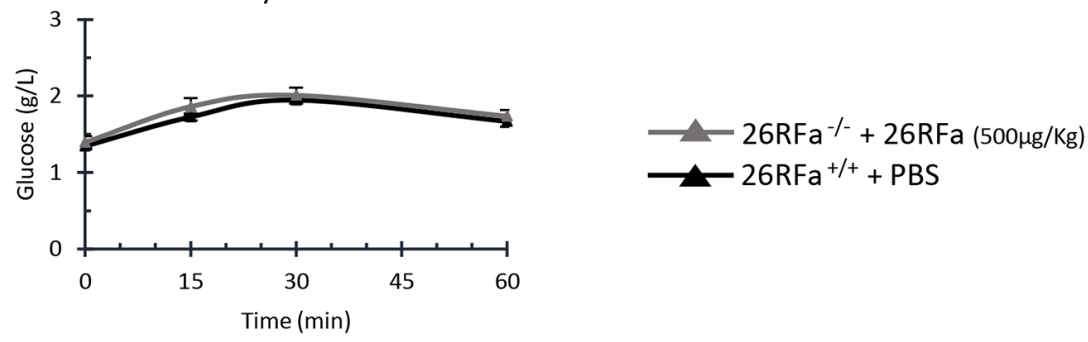

D

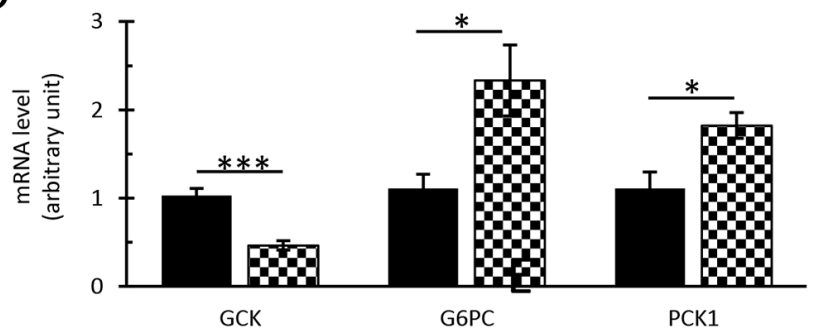

$26 \mathrm{RFa}^{+/+}$Fed
$26 \mathrm{RFa}^{+/+}$Fasted

$E$

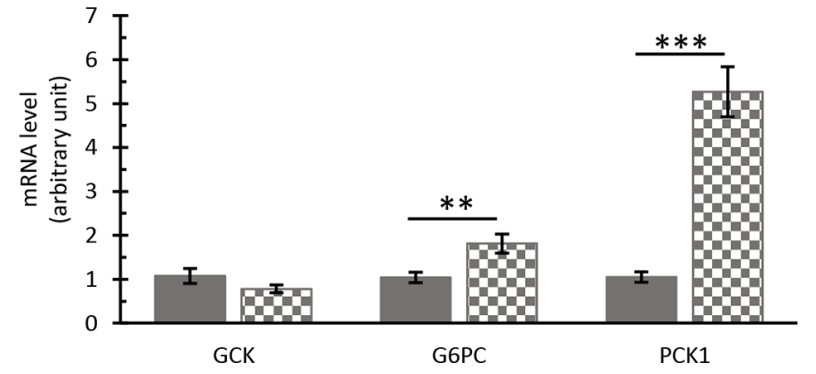

$26 \mathrm{RFa}^{-/-} \mathrm{Fed}$

$26 \mathrm{RFa}^{-/-}$Fasted

Figure 4 Glycemic phenotype of 26RFa-deficient mice 2. (A) Evaluation of plasma glucose levels in $26 \mathrm{RFa}^{-/-}, 26 \mathrm{RFa}^{+/-}$and $26 \mathrm{RFa}^{+/+}$mice during an insulin tolerance test ( $\mathrm{n}=13-18$ per group). (B) Evaluation of plasma glucose levels in $26 \mathrm{RFa}^{-/-}$, $26 \mathrm{RFa}^{+/-}$and $26 \mathrm{RFa}^{+/+}$mice during a pyruvate tolerance test $(n=10-14$ per group). (C) Evaluation of plasma glucose levels in $26 \mathrm{RFa}^{-1-}$ mice that received an intraperitoneal dose of $26 \mathrm{RFa}(500 \mu \mathrm{g} / \mathrm{kg})$ during a pyruvate tolerance test $(\mathrm{n}=8$ per group). (D, E) Expression of the liver enzymes glucokinase (GCK), glucose 6 phosphatase (G6PC) and phosphoenolpyruvate carboxykinase 1 (PCK1) in fasted or fed conditions of $26 \mathrm{RFa}^{+/+}$(D) and 26RFa ${ }^{-/-}$mice $(E)$ ( $n=8$ per group). Data presented as mean \pm SEM of 3 independent experiments; ${ }^{*} p<0.05,{ }^{* \star} \mathrm{p}<0.01,{ }^{* \star *} \mathrm{p}<0.00126 \mathrm{RFa}^{-/-}$versus $26 \mathrm{RFa}^{+/+}$mice. PBS, phosphate buffer saline. 

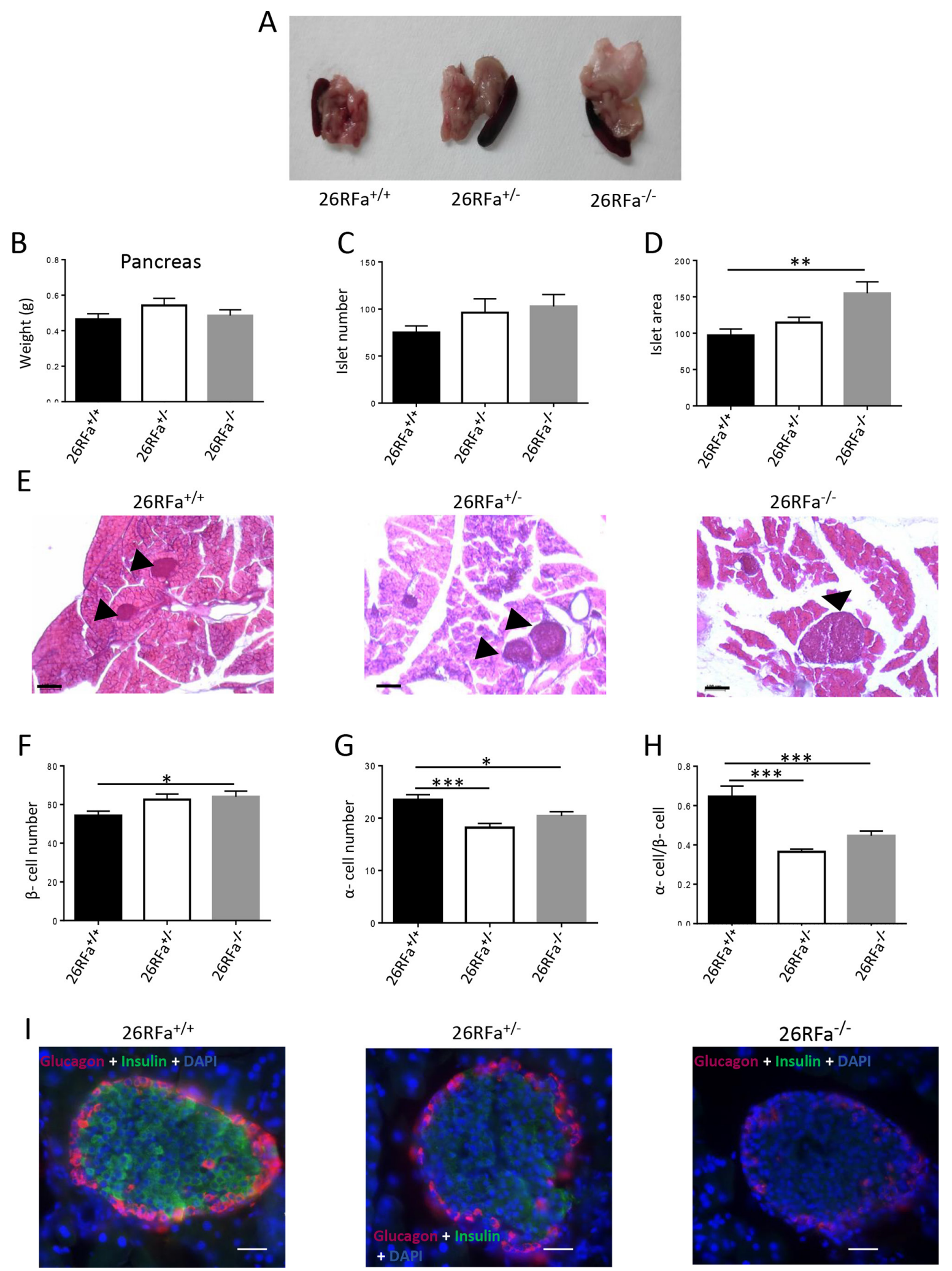

Figure 5 Pancreatic phenotype of 26RFa-deficient mice. (A, B) Representative photomicrographs of freshly dissected pancreas of $26 \mathrm{RFa}^{-/-}, 26 \mathrm{RFa}^{+/-}$and $26 \mathrm{RFa}^{+/+}$mice with their respective weights ( $\mathrm{n}=8$ per group). (C, D) Quantitative analysis of the number of pancreatic islets and their areas in $26 \mathrm{RFa}^{-/-}, 26 \mathrm{RFa}^{+/-}$and $26 \mathrm{RFa}^{+/+}$mice $(\mathrm{n}=5$ per group). Data presented as mean $\pm S E M ;{ }^{* *} p<0.01$. (E) Representative photomicrographs showing the difference in the size of the pancreatic islets of $26 \mathrm{RFa}^{-/-}, 26 \mathrm{RFa}^{+/-}$and 26RFa ${ }^{+/+}$mice (arrowheads). (F-H) Quantitative analysis of the number of $\beta$ and $\alpha$ cells per pancreatic islet and their ratio in $26 \mathrm{RFa}^{-/-}, 26 \mathrm{RFa}^{+/-}$and $26 \mathrm{RFa}^{+/+}$mice $(\mathrm{n}=5$ per group). (I) Representative photomicrographs of pancreatic islets of $26 \mathrm{RFa}^{-/-}, 26 \mathrm{RFa}^{+/-}$and $26 \mathrm{RFa}^{+/+}$mice labeled with an insulin antibody (green), a glucagon antibody (red) and DAPI (blue), showing that the intensity of the insulin and glucagon immunostaining is much lower in the $26 \mathrm{RFa}^{-1-}$ mice than in the $26 \mathrm{RFa}^{+/+}$mice. Data presented as mean $\pm \mathrm{SEM} ;{ }^{*} \mathrm{p}<0.05,{ }^{* *} \mathrm{p}<0.01,{ }^{* * *} \mathrm{p}<0.001$. Scale bar: $100 \mu \mathrm{m}$. 
higher in the $26 \mathrm{RFa}^{-/-}$mice versus the $26 \mathrm{RFa}^{+/+}$mice $(p<0.05)$ (figure 5F). Conversely, the number of $\alpha$ cells per islet was significantly lower in the $26 \mathrm{RFa}^{+/-}$and $26 \mathrm{RFa}^{-/-}$mice versus the $26 \mathrm{RFa}^{+/+}$mice $(\mathrm{p}<0.05$ and $\mathrm{p}<0.001$ ) (figure 5G). Consequently, the ratio of $\alpha$ cells to $\beta$ cells per islet was significantly lower in the heterozygous and $\mathrm{KO}$ mice as compared with the wild-type animals $(\mathrm{p}<0.001)$ (figure $5 \mathrm{H})$. Triple labeling experiments revealed that the intensity of insulin and glucagon immunostaining was much lower in the 26RFa-deficient mice versus the wild-type animals, whereas in the heterozygous mice the intensity of immunostaining of the two hormones was between the $26 \mathrm{RFa}^{-/-}$and the $26 \mathrm{RFa}^{+/+}$ mice (figure 5I). The iDISCO approach confirmed that the intensity of the insulin immunostaining was much higher in the wild-type animals (online supplementary video $\mathrm{S} 1$ ) in comparison with the 26RFa-KO mice (online supplementary video $\mathrm{S} 2$ ).

\section{DISCUSSION}

Accumulated data obtained during the last decade have promoted the evidence that the neuropeptide 26RFa plays a key role in the control of feeding behavior ${ }^{1013}$ and the regulation of glucose homeostasis. ${ }^{24} 252728$ Supporting this notion, it has been recently shown that acute administration of a GPR103 (the 26RFa receptor) antagonist decreases food intake ${ }^{30}$ and reduces the global glucoseinduced incretin effect as well as insulin sensitivity. ${ }^{28}$ However, chronic deficiency of 26RFa signaling on energy and glucose homeostasis remains to be elucidated. In the present study, we took advantage of a newly generated mouse line deficient in the 26RFa gene to decipher the phenotype of the $26 \mathrm{RFa}^{-1-}$ mice with regard to energy and glucose metabolism.

We first investigated the impact of chronic 26RFa depletion on various parameters of energy metabolism. Our data reveal that 26RFa deficiency does not alter body weight gain from postnatal week 5 to week 12 . We also show that at 2 months, the $26 \mathrm{RFa}^{-/-}, 26 \mathrm{RFa}^{+/-}$and $26 \mathrm{RFa}^{+/+}$ mice exhibited a similar body composition in terms of body weight, fat and lean mass. However, the 26RFa-KO mice showed a basal energy expenditure slightly higher than the heterozygous and their wild-type littermates. In addition, the 26RFa-deficient mice tended to eat and drink more than the wild-type mice and exhibited a more elevated $R Q$ although their locomotor activity is not altered. Collectively, these observations suggest that 26RFa-deficient mice have a basal metabolic rate slightly higher than the wild-type animals. The observation that deletion of the 26RFa gene does not impair daily feeding behavior and body weight is not surprising as disruption of other major orexigenic peptides such as NPY or ghrelin does not impact feeding behavior. ${ }^{31}{ }^{32}$ Indeed, it is accepted that the congenital lack of one regulatory peptide may be compensated by others as the control of feeding behavior is multifactorial. However, our data are in disagreement with a previous study reporting that disruption of the 26RFa (QRFP) gene results in a lower body weight due to a hypophagic behavior under both normal and high-fat-fed condition. ${ }^{33}$ We do not have any obvious explanation for this discrepancy between the two studies except that the strains of $26 \mathrm{RFa}^{-/-}$mice in the two studies are different (Okamoto et $_{\text {al }}{ }^{33}$ present study).

In the second part of our study, we have investigated the 'glycemic' phenotype of the 26RFa-deficient mice. We first show that depletion of the 26RFa gene has no impact on the evolution of glycemia and insulinemia measured in fed condition. Basal plasma glucose levels are not altered in fasting condition in the 26RFa-KO mice too. However, fasted insulinemia is significantly decreased in the $26 \mathrm{RFa}^{-/-}$mice as compared with the $26 \mathrm{RFa}^{+/-}$and $26 \mathrm{RFa}^{+/+}$mice. In addition, we show that, during a glucose tolerance test, the hyperglycemic peak is more sustained in the mice deficient in 26RFa and this is associated with a lower rise in plasma insulin, these effects being reversed by administration of exogenous 26RFa. By contrast, our data indicate that insulin sensitivity is not affected by the absence of endogenous 26RFa. Altogether, these findings reveal that depletion of $26 \mathrm{RFa}$ induces an alteration of glucose homeostasis that is due to a defect in insulin secretion but not in insulin sensitivity. Consistent with this finding, we have previously shown that 26RFa stimulates insulin secretion by the pancreatic $\beta$ cells $^{24}$ and that administration of a $26 \mathrm{RFa}$ receptor antagonist alters the antihyperglycemic response of the organism to a glucose challenge. ${ }^{28}$ Collectively, these data confirm that 26RFa is an important regulator of glucose homeostasis.

Our data also reveal that depletion of 26RFa induces a dysfunction in the regulation of glucose hepatic production. Indeed, the $26 \mathrm{RFa}$-deficient mice exhibited an increase in their glucose hepatic production that is associated with an upregulation of G6PC and PCK1, two key liver enzymes that trigger gluconeogenesis. We have previously reported that $26 \mathrm{RFa}$ exerts a crucial antihyperglycemic effect that is due to its incretin activity and its insulin-sensitive effect. ${ }^{24}$ Our present findings suggest that the inhibitory activity of $26 \mathrm{RF}$ a on hepatic glucose production also participates in the global antihyperglycemic effect of the peptide. However, we have also previously shown that the 26RFa receptor GPR103 is not expressed in the liver. ${ }^{24}$ This observation suggests that the inhibitory effect of 26RFa on glucose hepatic production is not a direct effect but rather an indirect effect, maybe mediated via its insulin-secreting activity as insulin is well known to inhibit hepatic glucose production.

One major phenotype of the 26RFa-deficient mice is the low plasma insulin levels in fasting conditions or in response to a glucose challenge. This led us to examine whether this decreased insulin production was associated with alteration in the morphology and physiology of the pancreas. Surprisingly, our quantitative analysis revealed that the pancreas of the mutant mice is bigger with larger pancreatic islets than their wild-type littermates with a higher number of $\beta$ cells/islet, which rather suggests an increased capacity of the pancreatic islets to produce and 
secrete insulin in the 26RFa-deficient mice. However, twodimensional and three-dimensional (3D) immunohistochemical labeling of the pancreatic islets with insulin antibodies shows that the intensity of insulin immunostaining in the $\beta$ cells of the the $26 \mathrm{RFa}^{-/-}$mice is much lower than that observed in $26 \mathrm{RFa}^{+/+}$mice, suggesting that the capacity of the $\beta$ cells to produce/secrete insulin is impaired in the mutant mice. We hypothesize that this altered insulin production may explain the lower plasma insulin levels observed in the 26RFa-deficient mice and that the increased number of pancreatic islets and $\beta$ cells observed in the mutant mice may reflect a compensatory mechanism of the organism to counterbalance the low capacity of the $\beta$ cells to produce insulin. We have previously shown in human ${ }^{25}$ and rodents ${ }^{24}$ that the $\beta$ cells of the pancreatic islets highly express $26 \mathrm{RF}$. According to this latter observation, we think that a potential role for $26 \mathrm{RFa}$ in the synthesis/production of insulin within the $\beta$ cells deserves further investigation.

Finally, our experiments indicate that the heterozygous mice have an intermediate 'glycemic' phenotype between those of the mutant and the wild-type animals.

In conclusion, the present study reveals that depletion of the 26RFa gene induces a substantial alteration in the regulation of glucose homeostasis, with in particular a deficit in insulin production by $\beta$ cells of the pancreatic islets. These original data confirm our previous studies, ${ }^{23}{ }^{24}$ supporting the idea that the neuropeptide $26 \mathrm{RFa}$ is a key regulator of glucose homeostasis and that dysfunction of the 26RFa/GPR103 peptidergic system may promote diabetes.

Contributors ME-M, MP and NC contributed to study design and interpretation, and wrote the manuscript. J-LdR, J-CdR, FK, ST, AA, MP and ME-M performed the in vivo experiments on mice. ST, FK, DG and MP contributed to the immunohistochemical experiments and their quantitative analysis. FK and ME-M contributed to the PCR experiments. AB and EN performed the insulin assays, and $\mathrm{JL}$ produced the synthetic 26RFa. GP and YA revised and approved the final version of the manuscript. NC is the guarantor of this work, and as such had full access to all the data in the study and takes responsibility for the integrity of the data and the accuracy of the data analysis.

Funding This work was supported by the Institut National de la Santé et de la Recherche Médicale (INSERM) (grant number: U1239), the University of Rouen, the Institute for Research and Innovation in Biomedicine (IRIB) (recurrent funding), the 'Fondation pour la Recherche Médicale' (grant number: DEA 20140629966), and the 'Société Francophone du Diabète' (grant number: R16038EE). The present study was also cofunded by the European Union and the Normandie Regional Council. Europe gets involved in Normandie with European Regional Development Fund (ERDF).

Competing interests None declared.

Patient consent for publication Not required.

Ethics approval All experimental procedures were approved by the Normandy Regional Ethics Committee (authorization: APAFIS\#11752-2017100916177319) and were carried out in accordance with the European Committee Council Directive of November 24, 1986 (86/609/EEC).

Provenance and peer review Not commissioned; externally peer reviewed.

Data availability statement Data are available upon reasonable request. All data relevant to the study are included in the article or uploaded as supplementary information.

Open access This is an open access article distributed in accordance with the Creative Commons Attribution Non Commercial (CC BY-NC 4.0) license, which permits others to distribute, remix, adapt, build upon this work non-commercially, and license their derivative works on different terms, provided the original work is properly cited, appropriate credit is given, any changes made indicated, and the use is non-commercial. See: http://creativecommons.org/licenses/by-nc/4.0/.

ORCID iD

Nicolas Chartrel http://orcid.org/0000-0002-3469-3736

\section{REFERENCES}

1 WHO, Obesity and Overweight, 2019. Available: http://www.who.int/ mediacentre/factsheets/fs311/en/

2 Imai Y, Patel HR, Hawkins EJ, et al. Insulin secretion is increased in pancreatic islets of neuropeptide $\mathrm{Y}$-deficient mice. Endocrinology 2007;148:5716-23

3 Ouedraogo R, Näslund E, Kirchgessner AL. Glucose regulates the release of orexin-A from the endocrine pancreas. Diabetes 2003:52:111-7.

4 Verhulst P-J, Depoortere I. Ghrelin's second life: from appetite stimulator to glucose regulator. World J Gastroenterol 2012:18:3183-95.

5 Huising MO, van der Meulen T, Vaughan JM, et al. Crfr1 is expressed on pancreatic beta cells, promotes beta cell proliferation, and potentiates insulin secretion in a glucose-dependent manner. Proc Natl Acad Sci U S A 2010;107:912-7.

6 Yue $\mathrm{P}$, Jin $\mathrm{H}$, Aillaud $\mathrm{M}$, et al. Apelin is necessary for the maintenance of insulin sensitivity. Am J Physiol Endocrinol Metab 2010;298:E59-67.

7 Plum L, Belgardt BF, Brüning JC. Central insulin action in energy and glucose homeostasis. J Clin Invest 2006;116:1761-6.

8 Coppari R. Hypothalamic neurones governing glucose homeostasis. $J$ Neuroendocrinol 2015;27:399-405.

9 Fujikawa T, Berglund ED, Patel VR, et al. Leptin engages a hypothalamic neurocircuitry to permit survival in the absence of insulin. Cell Metab 2013;18:431-44.

10 Chartrel N, Dujardin C, Anouar Y, et al. Identification of 26RFa, a hypothalamic neuropeptide of the RFamide peptide family with orexigenic activity. Proc Natl Acad Sci U S A 2003;100:15247-52.

11 Fukusumi S, Yoshida H, Fujii R, et al. A new peptidic ligand and its receptor regulating adrenal function in rats. J Biol Chem 2003;278:46387-95.

12 Jiang Y, Luo L, Gustafson EL, et al. Identification and characterization of a novel RF-amide peptide ligand for orphan Gprotein-coupled receptor SP9155. J Biol Chem 2003;278:27652-7.

13 Chartrel N, Alonzeau J, Alexandre D, et al. The RFamide neuropeptide $26 \mathrm{RFa}$ and its role in the control of neuroendocrine functions. Front Neuroendocrinol 2011;32:387-97.

14 Chartrel N, Picot M, El Medhi M, et al. The neuropeptide 26RFa (QRFP) and its role in the regulation of energy homeostasis: a minireview. Front Neurosci 2016;10:549.

15 Takayasu S, Sakurai T, Iwasaki S, et al. A neuropeptide ligand of the G protein-coupled receptor GPR103 regulates feeding, behavioral arousal, and blood pressure in mice. Proc Natl Acad Sci U S A 2006;103:7438-43.

16 Leprince J, Bagnol D, Bureau R, et al. The Arg-Phe-amide peptide 26RFa/glutamine RF-amide peptide and its receptor: IUPHAR review 24. Br J Pharmacol 2017;174:3573-607.

17 Bruzzone F, Lectez B, Tollemer $\mathrm{H}$, et al. Anatomical distribution and biochemical characterization of the novel RFamide peptide $26 \mathrm{RFa}$ in the human hypothalamus and spinal cord. J Neurochem 2006;99:616-27.

18 Bruzzone F, Lectez B, Alexandre D, et al. Distribution of 26RFa binding sites and GPR103 mRNA in the central nervous system of the rat. J Comp Neurol 2007:503:573-91.

19 Moriya R, Sano H, Umeda T, et al. Rfamide peptide QRFP43 causes obesity with hyperphagia and reduced thermogenesis in mice. Endocrinology 2006;147:2916-22.

20 Lectez B, Jeandel L, El-Yamani F-Z, et al. The orexigenic activity of the hypothalamic neuropeptide $26 \mathrm{RFa}$ is mediated by the neuropeptide $\mathrm{Y}$ and proopiomelanocortin neurons of the arcuate nucleus. Endocrinology 2009;150:2342-50.

21 Ukena K, Tachibana T, Iwakoshi-Ukena E, et al. Identification, localization, and function of a novel avian hypothalamic neuropeptide, 26RFa, and its cognate receptor, G protein-coupled receptor-103. Endocrinology 2010;151:2255-64.

22 Liu Y, Zhang Y, Li S, et al. Molecular cloning and functional characterization of the first non-mammalian 26RFa/QRFP orthologue in goldfish, Carassius auratus. Mol Cell Endocrinol 2009;303:82-90.

23 Primeaux SD, Blackmon C, Barnes MJ, et al. Central administration of the RFamide peptides, QRFP-26 and QRFP-43, increases high fat food intake in rats. Peptides 2008;29:1994-2000. 
24 Prévost G, Jeandel L, Arabo A, et al. Hypothalamic neuropeptide $26 \mathrm{RFa}$ acts as an incretin to regulate glucose homeostasis. Diabetes 2015;64:2805-16.

25 Prévost G, Picot M, Le Solliec M-A, et al. The neuropeptide 26RFa in the human gut and pancreas: potential involvement in glucose homeostasis. Endocr Connect 2019;8:941-51.

26 Mulumba M, Jossart C, Granata R, et al. GPR103b functions in the peripheral regulation of adipogenesis. Mol Endocrinol 2010;24:1615-25.

27 Granata R, Settanni F, Trovato L, et al. Rfamide peptides 43RFa and $26 \mathrm{RFa}$ both promote survival of pancreatic $\beta$-cells and human pancreatic islets but exert opposite effects on insulin secretion. Diabetes 2014;63:2380-93.

28 Prévost G, Arabo A, Le Solliec MA, et al. The neuropeptide $26 \mathrm{RFa}$ is a key regulator of glucose homeostasis and its activity is markedly altered in diabetes. Am J Physiol Endocrinol Metab 2019;317:E147-57.

29 Belle M, Godefroy D, Couly G, et al. Tridimensional visualization and analysis of early human development. Cell 2017;169:161-73.

30 Georgsson J, Bergström F, Nordqvist A, et al. GPR103 antagonists demonstrating anorexigenic activity in vivo: design and development of pyrrolo[2,3-c]pyridines that mimic the C-terminal Arg-Phe motif of QRFP26. J Med Chem 2014;57:5935-48.

31 Palmiter RD, Erickson JC, Hollopeter G, et al. Life without neuropeptide Y. Recent Prog Horm Res 1998;53:163-99.

32 Sun Y, Ahmed S, Smith RG. Deletion of ghrelin impairs neither growth nor appetite. Mol Cell Biol 2003;23:7973-81.

33 Okamoto K, Yamasaki M, Takao K, et al. QRFP-deficient mice are hypophagic, lean, hypoactive and exhibit increased anxiety-like behaviour. Plos One 2016;10:1371. 